\title{
Growth performance of African catfish Clarias gariepinus cultured in biofloc system at high stocking density
}

\section{Kinerja pertumbuhan lele dumbo Clarias gariepinus yang dipelihara pada sistem bioflok dengan padat penebaran tinggi}

\author{
Petrus Hary Tjahja Soedibya*, Taufik Budhi Pramono, Emyliana Listiowati \\ Study Program of Aquaculture, Faculty of Fisheries and Marine Science \\ Jenderal Soedirman University, Purwokerto, Central Java, Indonesia \\ *E-mail: hary_tjahja@yahoo.co.id
}

\begin{abstract}
This study was aimed to analyze the growth performance of African catfish Clarias gariepinus cultured in the biofloc system at high stocking density. African catfish with an average weight of $1.85 \pm 0.09 \mathrm{~g}$ were cultured in four units of tarpaulin tank at a diameter of $1.72 \mathrm{~m}$ and a height of $1.05 \mathrm{~m}$ with a volume of $\pm 2,000 \mathrm{~L}$ at the different density of $1,000 \mathrm{fish} / \mathrm{m}^{3} ; 1,500 \mathrm{fish} / \mathrm{m}^{3} ; 2,000 \mathrm{fish} / \mathrm{m}^{3} ; 2,500 \mathrm{fish} / \mathrm{m}^{3}$. During rearing period, fish were given the artificial feed with protein contents of $28.75 \%$ with the frequency of twice a day, as much as $3 \%$ of the body weight. The results showed that different treatment of high stocking density in the biofloc system had a significant effect on the absolute growth rate, lipid retention and energy retention $(\mathrm{P}<0.05)$ but not significant effect on daily growth rate. The results showed that the highest lipid retention and energy retention were found in the group of fish treated at a stocking density of 2,500 fish $/ \mathrm{m}^{3}$ but declining protein retention and growth in fish occurred. The highest absolute growth rate and daily growth rate were shown by treatment with a stocking density of $1,500 \mathrm{fish} / \mathrm{m}^{3}$.
\end{abstract}

Keywords: growth, stocking density, biofloc

\begin{abstract}
ABSTRAK
Penelitian ini bertujuan untuk menganalisis performa pertumbuhan ikan lele dumbo Clarias gariepinus yang dipelihara pada sistem bioflok dengan padat penebaran tinggi. Ikan uji memiliki berat rata-rata $1,85 \pm 0,09 \mathrm{~g}$ yang dipelihara pada kolam terpolin berdiameter $1,72 \mathrm{~m}$ dan tinggi 1,05 m dengan volume air $\pm 2.000 \mathrm{~L}$ sebanyak empat unit dengan kepadatan yang berbeda yaitu $1.000 \mathrm{ekor} / \mathrm{m}^{3}, 1.500 \mathrm{ekor} / \mathrm{m}^{3}, 2.000 \mathrm{ekor} / \mathrm{m}^{3}, 2.500 \mathrm{ekor} / \mathrm{m}^{3}$. Selama 40 hari masa pemeliharaan, ikan diberi pakan buatan berkadar protein $28,75 \%$ dengan frekwensi dua kali sehari, sebanyak 3\% dari berat tubuh. Hasil penelitian menunjukkan bahwa perlakuan perbedaan padat penebaran tinggi pada sistem bioflok memberikan pengaruh yang nyata terhadap pertumbuhan mutlak, retensi lemak dan retensi energi $(\mathrm{P}<0,05)$ namun tidak memberikan pengaruh nyata terhadap laju pertmbuhan harian. Hasil penelitian menunjukkan bahwa semakin tinggi padat penebaran terjadinya peningkatan retensi lemak dan retensi energi yaitu pada perlakuan padat penebaran $2.500 \mathrm{ekor} / \mathrm{m}^{3}$ tetapi terjadi penurunan nilai retensi protein dan pertumbuhan pada ikan. Nilai pertumbuhan mutlak tertinggi ditunjukkan oleh perlakuan dengan padat penebaran $1.500 \mathrm{ekor} / \mathrm{m}^{3}$.
\end{abstract}

Kata kunci: pertumbuhan, padat tebar, bioflok

\section{INTRODUCTION}

Catfish is a freshwater aquaculture commodity widely cultured in Indonesia. Fast growth of catfish is one of the reasons to farm this fish. Moreover, market demand for catfish also continues to increase over years for its delicious taste and relatively affordable price (Zidni et al., 2013). These reasons motivate fish farmers to continue increasing catfish production; therefore they perform fish culture through the intensive system. This system is characterized by increasing stocking density and supplementary feeding. This condition results in declining water quality of maintenance media due to high metabolic waste and uneaten feed (Sidik et al., 2002).

Implementation of intensive fish culture has an impact on increasing quantity of feed given to 
fish. This causes several problems including the high need for feed and the cost of providing the feed (Ballester et al., 2010; Furtado et al., 2011). Increase in aquaculture production correlates with the application of intensive aquaculture system and the increasing of feeding. Feed is one of the main production factors in intensive aquaculture in which feed cost allocation reaches $60 \%$. Implementation of intensive fish culture and feeding in aquaculture industry will lead to two big problems. First, low feed utilization by fish which reaches only $30 \%$ and results in production inefficiency (Avnimelech, 2007; Ekasari, 2009). Second, rapid accumulation of residual feed, metabolic and toxic compound which has an impact on the emergence of disease or fish death which eventually cause loss and the environmental problem (Avnimelech, 2007; de Schryver et al., 2008; Ekasari, 2009).

Various technologies of fish culture start to be developed to answer the problem. One aquaculture technology that has already been developed is the RAS or recirculating aquaculture system, by using different types of biofilter in waste treatment. However, this RAS technology requires high investment and operating cost, includes the cost of energy and manpower (Badiola et al., 2012). Currently, the environmentally friendly technology called biofloc is being developed. The BFT or Bio-flocs technology is hoped to solve the problem of feed inefficiency, production cost, water quality, productivity, and profit optimization in order to reduce aquaculture waste (Avnimelech, 2006; 2007; de Schryver et al., 2008). Biofloc technology is an aquaculture technology which is based on the principle of inorganic nitrogen assimilation (ammonia, nitrite, and nitrate) by the microbial community (heterotrophic bacteria) in the culture media as the source of nutrition for bacteria (De Schryver et al., 2008).

Increase in stocking density in African catfish culture is able to be optimized through the system of biofloc technology. Soedibya and Listiowati (2014) have performed the application of African catfish culture using biofloc technology at a density of 400, 500, 750 and 1,000 fish/pond. The result showed that the growth of catfish between treatments was significantly different and the floc volume tended to be higher along with the increasing fish stocking density; thus enhanced its contribution as the source of live food. One effort to improve aquaculture productivity is possible to be done through an increase in stocking density. Yet, the growth performance of African catfish at high stocking density in biofloc technology system should be further evaluated. This study was aimed to analyze the growth performance of African catfish Clarias gariepinus cultured in the biofloc system at high stocking density.

\section{MATERIALS AND METHODS}

\section{Fish maintenance}

Catfish culture media used was four units of tarpaulin pond which had a diameter of $1.72 \mathrm{~m}$ and $1.05 \mathrm{~m}$ height with the volume of $\pm 2,438 \mathrm{~L}$. The ponds were cleaned, and further filled with water amounted to 2,000 Liter. Later, preparation of biofloc media was done through the addition of the salt of $500 \mathrm{gram} /$ pond, followed by the addition of probiotic of $5 \mathrm{~mL} / \mathrm{m}^{3}$ and molasses of $10 \mathrm{~mL} / \mathrm{m}^{3}$ for one week until the water turned blackish and tiny clumps were formed which indicated that the flocs started being formed. Each container was filled with African catfish which had a weight of $1.85 \pm 0.09 \mathrm{~g}$ at different density.

Listed below is the stocking density treatment of African catfish.

1. African catfish at the stocking density of $1,000 \mathrm{fish} / \mathrm{m}^{3}$.

2. African catfish at the stocking density of $1,500 \mathrm{fish} / \mathrm{m}^{3}$.

3. African catfish at the stocking density of 2,000 fish $/ \mathrm{m}^{3}$.

4. African catfish at the stocking density of 2,500 fish $/ \mathrm{m}^{3}$.

Feeding was done daily about $3 \%$ of fish body biomass with feeding frequency of twice a day, namely at 09.00 WIB and 16.00 WIB. Feeding portion in the morning was $40 \%$ and in the afternoon was $60 \%$ for 40 days of maintenance. The feed used was commercial feed with the protein content of $28.75 \%$ (PAU, 2016). To maintain the water quality remained in good condition, monitoring of several water quality parameters included temperature, $\mathrm{pH}$, and dissolved oxygen was performed daily, both in the morning and in the afternoon. Furthermore, nitrite, nitrate, and ammonia were measured at the beginning, in the middle, and at the end of fish culture.

\section{Parameter observed}

Parameter observed during fish culture included absolute growth rate, daily growth rate, energy retention, protein retention, and lipid retention as well as water quality. The absolute growth rate and daily growth rate data collection 
was done once a week, for 35 days of maintenance period by taking the fish sample, that was $2.5 \%$ of a total number of fish stocked in each pond. Fish collected from each pond were further weighed for their body biomass and the data were recorded. The data of absolute growth rate and daily growth rate (DGR) were calculated using the formula which referred to Sukardi and Yuwono (2010) as follows:

$$
\begin{aligned}
& \text { Absolute growth }(\mathrm{g})= \\
& \text { Final weight }(\mathrm{g}) \text { - Initial weight }(\mathrm{g}) \\
& \text { Daily growth rate (DGR) (g/day) = } \\
& \text { final weight }(\mathrm{g}) \text {-initial weight }(\mathrm{g}) \\
& \text { number of maintenance (day) }
\end{aligned}
$$

Data collection for nutrient retention which consisted of energy retention, protein retention and lipid retention was performed at the beginning and at the end of maintenance period. Data collection for crude protein content and crude lipid content of fish body at the beginning and at the end of maintenance was done by performing proximate analysis of fish body sample which had already been dried and smoothed. Measurement of fish body energy was conducted using bomb calorimeter. Moreover, the calculation of protein retention and lipid retention was done using the formula according to Sukardi and Yuwono (2010), while energy retention (ANER) was computed based on Watanabe et al. (2001):

$$
\text { Protein retention }(\mathrm{PR})=[(\mathrm{F}-\mathrm{I}) / \mathrm{P}] \times 100
$$

$$
\begin{aligned}
& \text { Note: } \\
& \mathrm{PR}=\text { protein retention }(\%) \\
& \mathrm{F}= \\
& \begin{aligned}
& \text { the amount of protein in the fish bodyat } \\
\mathrm{I}= & \text { the amount of protein in the fish body at } \\
& \text { the initial of rearing period }(\mathrm{g}) \\
\mathrm{P}= & \text { the amount of protein in the feed } \\
& \text { consumed during the rearing period }(\mathrm{g})
\end{aligned}
\end{aligned}
$$

$$
\text { Lipid retention }(\mathrm{LR})=[(\mathrm{F}-\mathrm{I}) / \mathrm{P}] \times 100
$$

Note:

$\mathrm{LR}=$ lipid retention $(\%)$

$\mathrm{F}=$ the amount of lipid in the fish body at the end of rearing period $(\mathrm{g})$

I = the amount of lipid in the fish body at the initial of the rearing period $(\mathrm{g})$

$\mathrm{P} \quad=$ the amount of lipid in the feed consumed during the rearing period $(\mathrm{g})$
Energy retention/ER $($ ANER $)=$

$[((\mathrm{Wt} \times \mathrm{Et})-(\mathrm{Wo} \times \mathrm{Eo})) / \mathrm{Ep}] \times 100$

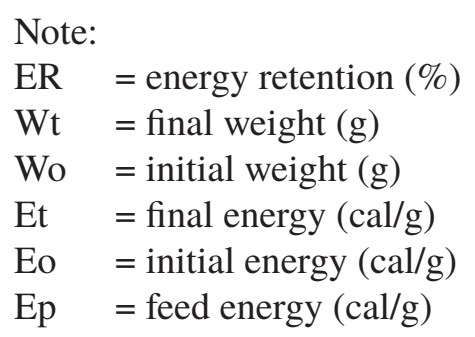

Supporting parameter measured was water quality which included temperature, dissolved oxygen, ammonia, nitrite, and nitrate. Temperature data were observed daily, in the morning and in the afternoon. Data of dissolved oxygen, ammonia, nitrite and nitrate content were observed at the beginning, in the middle, and at the end of fish culture.

\section{Data analysis}

This study applied completely randomized design with four treatments and individual replication. To know the effect of treatment on the variable of daily growth rate, absolute growth, protein retention, and lipid retention, analysis of variance at the confidence level of $95 \%$ was performed and further was continued with the least significant difference test using the software of SPSS 17.0. Supporting parameter of water quality was analyzed descriptively.

\section{RESULTS AND DISCUSSION}

The high stocking density of African catfish in the biofloc system on growth performance of experimental fish cultured for 40 days showed a statistically significantly different result $(\mathrm{P}<0.05)$ on the absolute growth value (Figure 1). Yet, no significant difference was found in the value of daily growth rate $(\mathrm{P}>0.05)$ (Figure 2$)$.

The growth data of treatment three and four in Figure 1 showed decreasing absolute growth rate at stocking density higher than $1,500 \mathrm{fish} / \mathrm{m}^{3}$. This finding was in accordance with the research conducted by Hermawan et al. (2014) that specific growth rate of catfish seed in the study of different stocking density in intensive culture with the biofloc system in each treatment was significantly different $(\mathrm{P}<0.05)$.

The similar result was reported by Malik et al. (2014) who reared Pangasius hypophthalmus seed at different stocking density and found that the lowest stocking density, that was 100 fish/ 
pond, obtained the best growth value compared with the stocking density of $150 \mathrm{fish} /$ pond and $200 \mathrm{fish} /$ pond. It shows that growth rate will increase when stocking density decreases. This condition is caused by the reason that fish will get more space to move, more feed, more dissolved oxygen as well as facing decreased competition at low stocking density. According to Nwiepie $e t$ al. (2015), at stocking density higher than $15 \mathrm{fish} /$ Liter, catfish C. gariepinus will experience stress as a result of increasing competition for food thus the growth will decline.

Moreover, Hickling (1971) mentioned that fish growth will be faster if fish are cultured at low stocking density. On the contrary, the growth will be low at high stocking density. Increase in density will be followed by decreasing growth (critical standing crop) and when it reaches certain extent (carrying capacity), the growth will completely stop. Factors affecting carrying capacity are water quality, feed, and fish size. Space of movement and food supply are factors that also affect the fish growth in which fish will grow well when those two factors are fulfilled, yet low growth will occur if one of both factors are absent or not adequate.

Treatment two with the stocking density of $1,500 \mathrm{fish} / \mathrm{m}^{3}$ was able to utilize feed well which was reflected in higher absolute growth rate compared to other treatments. It is because the addition of molasses to the maintenance media

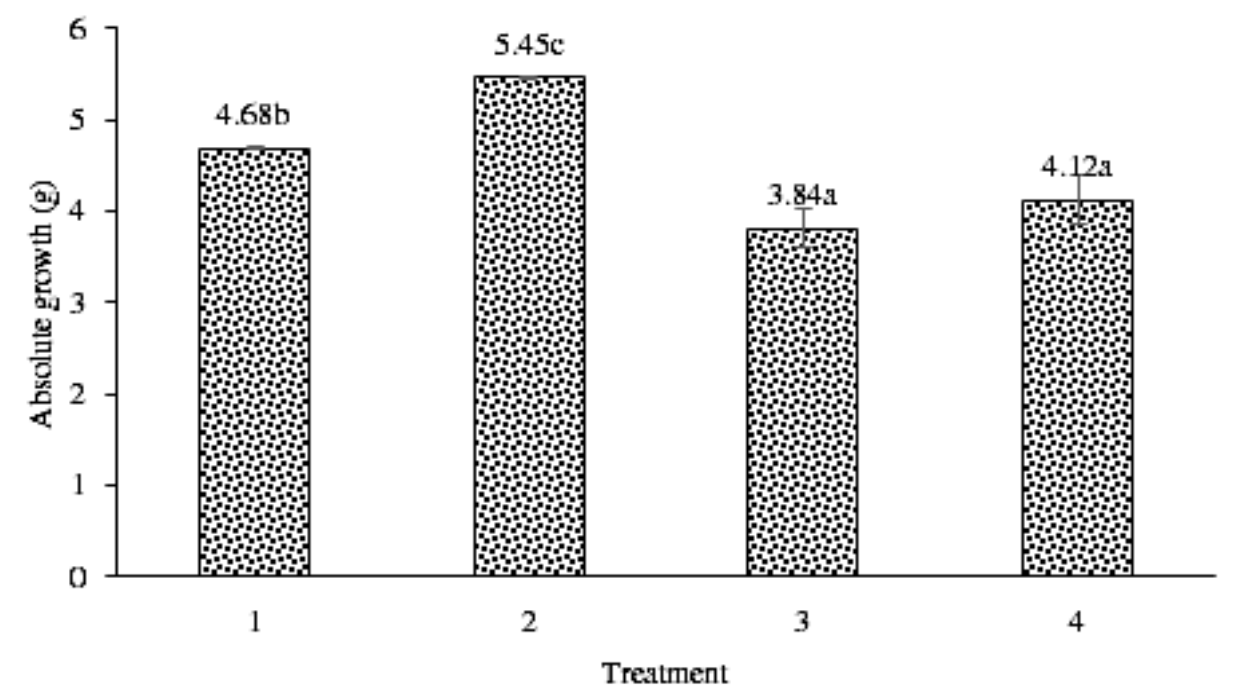

Figure 1. Absolute growth of African catfish Clarias gariepinus. 1. Biofloc pond at the stocking density of 1,000 fish $/ \mathrm{m}^{3} ; 2$. The stocking density of $1,500 \mathrm{fish} / \mathrm{m}^{3} ; 3$. The stocking density of $2,000 \mathrm{fish} / \mathrm{m}^{3} ; 4$. The stocking density of $2,500 \mathrm{fish} / \mathrm{m}^{3}$. Value with different letter showed the significantly different result of ANOVA $(\mathrm{P}<0.05)$.

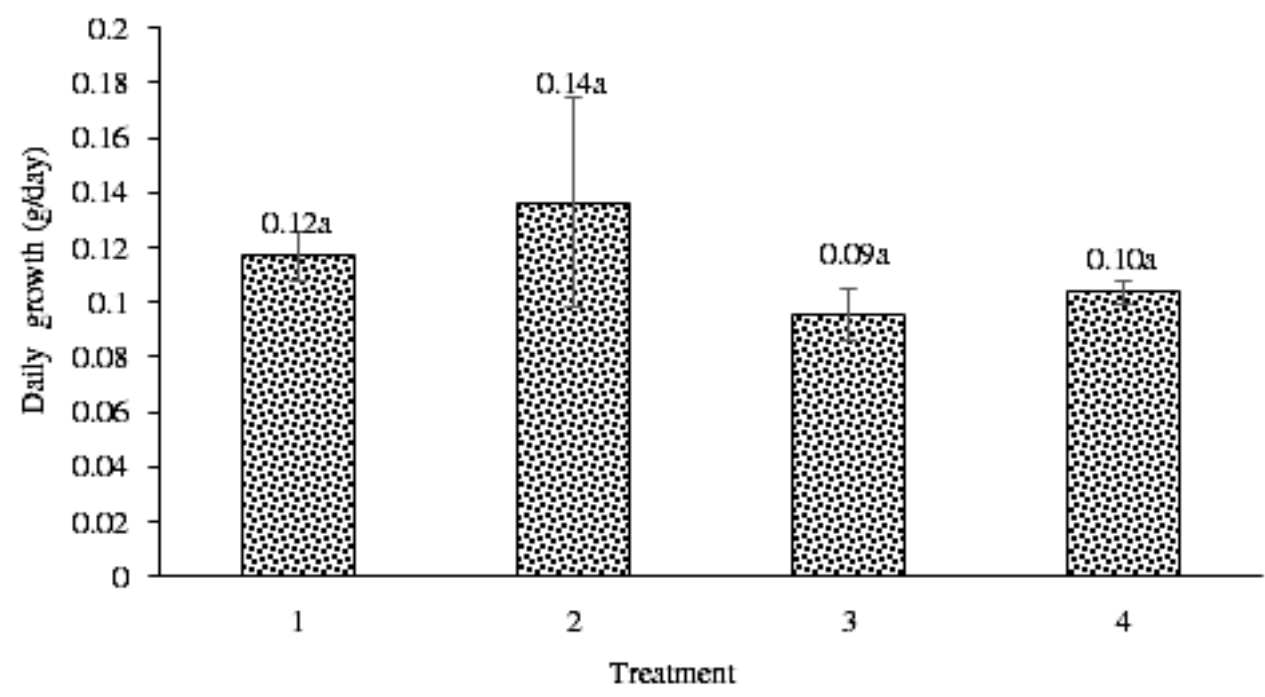

Figure 2. The average daily growth rate of African catfish Clarias gariepinus. 1. Biofloc pond at the stocking density of $1,000 \mathrm{fish} / \mathrm{m}^{3} ; 2$. The stocking density of $1,500 \mathrm{fish} / \mathrm{m}^{3} ; 3$. The stocking density of $2,000 \mathrm{fish} / \mathrm{m}^{3} ; 4$. The stocking density of $2,500 \mathrm{fish} / \mathrm{m}^{3}$. Value with different letter showed the significantly different result of ANOVA $(\mathrm{P}<0.05)$. 
which applied biofloc technology stimulates the growth of heterotrophic bacteria thus forming floc biomass which is able to play a role as live food for fish. Based on Crab et al. (2012), feed protein can be produced in situ, that is in the maintenance media, through the implementation of biofloc technology.

The contribution of flocs available for 24 hours also has an effect on the growth. The flocs formed can be used by fish as live food. The floc protein in treatment two was higher, amounted to $22.24 \%$, while in treatment one, treatment three, and treatment four, the floc protein contents were respectively $19.25 \%, 15.83 \%$, and $21.60 \%$ at the same feed protein content (pellet) given in each treatment, namely $28.75 \%$. Utilization of microbial protein as food depends on the fish ability to harvest, digest, and use the bacteria for its growth which is affected by fish type (food and feeding habit), fish size, floc size, and floc density (Avnimelech, 2007). Different floc protein content is one of the reasons for different fish growth rate in each treatment. It is due to various factors including water quality and organic matter. As mentioned by de Schryver et al. (2008), mixing intensity, level of dissolved oxygen in the water, type and amount of organic matter supply to the water, water temperature, and $\mathrm{pH}$ may determine the microbial composition, morphological structure, volume, and nutritional value of biofloc.

Treatment four showed that the highest lipid retention obtained was $129.74 \pm 40.4 \%$ (Figure 3 ). It is expected that fish in treatment four at the stocking density of $2,500 \mathrm{fish} / \mathrm{m}^{3}$ tended to perform less activity for their limited space of movement due to extremely high stocking density, thus lipid was more stored in the body than being used to do an activity. As stated by Hermawan et al. (2012), high stocking density influenced fish activity and space of movement. Increasing stocking density will result in declining space of movement and activity of fish.

The higher lipid retention produced, the higher amount of dietary lipid stored as the energy reserve. This is confirmed by Ekasari et al. (2014) who mentioned that lipid from the feed can be used as an important energy source for fish, therefore protein consumed from the feed can be optimally utilized for fish growth.

The result of protein retention value in treatment two showed the highest value compared with other treatments (Figure 4). It is expected due to the reason that African catfish in treatment two was able to utilize dietary protein and biofloc protein to be stored within the body and will be used for growth as supported by the result that higher absolute growth was obtained in this treatment. It is in accordance with the opinion of Apriyani et al. (2006) that the increased protein retention value in fish maintained in biofloc media was caused by the existence of food source in biofloc media (live food) which further were used by fish as protein source aside from feed hence more protein is synthesized into body protein.

Based on the observation result on catfish maintained for 40 days in the biofloc system,

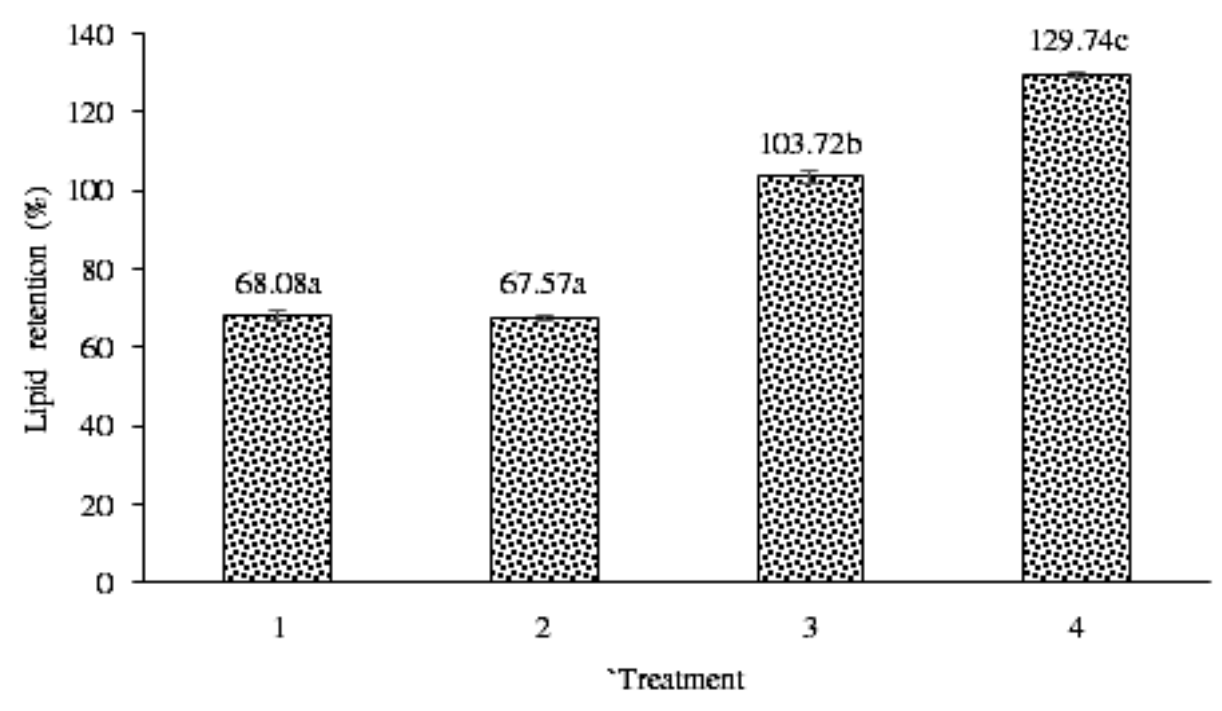

Figure 3. Average lipid retention of African catfish Clarias gariepinus. 1. Biofloc pond at the stocking density of $1,000 \mathrm{fish} / \mathrm{m}^{3} ; 2$. The stocking density of $1,500 \mathrm{fish} / \mathrm{m}^{3} ; 3$. The stocking density of $2,000 \mathrm{fish} / \mathrm{m}^{3} ; 4$. The stocking density of 2,500 fish $/ \mathrm{m}^{3}$. Value with different letter showed the significantly different result of ANOVA $(\mathrm{P}<0.05)$. 
initial fish energy was $7,106.6768 \mathrm{cal} / \mathrm{g}$, while dietary energy provided was $4,919.6554 \mathrm{cal} / \mathrm{g}$, which produced energy retention in a range of $118-244 \%$. According to Buttery and Lindsay (1980), normal energy retention is 60-68\%, while the research finding showed the higher percentage, namely higher than $100 \%$ (Figure5). This situation was possible due to the reason that only small portion of the energy produced that was released by the body for metabolism, reproductive activity, biosynthesis, or even lost in the form of heat. Energy produced was mostly stored because fish had less activity like swimming due to limited space of movement. According to Fujaya (2004), the rate of metabolism is affected by biotic factors such as temperature, salinity, oxygen, carbon dioxide, ammonia, $\mathrm{pH}$, photoperiodism, season, and pressure; and abiotic factors like activity, weight, sex, age, schooling, stress, fasting, and feeding ratio. It is in line with Shafrudin et al. (2006) that metabolism has a big portion in using energy compared to growth, for instance: energy for activity and swimming.

Treatment one, two, and three obtained lower energy retention than treatment four. It is expected due to the possibility that dietary energy given to catfish, particularly in treatment three, was used for the high activity, thus there was lower energy stored in the fish body. Yuwono and Sukardi (2001) said that most dietary energy consumed by fish will be lost in the form of heat and only about one-fifth of total dietary energy obtained is used for growth.

The result of water quality measurement indicated that water quality was still in the appropriate condition for catfish culture (Table 1). At the beginning of the study, the range of ammonia level was $0.9-1.8 \mathrm{mg} / \mathrm{L}$. High ammonia level was caused by the accumulation of fish metabolic waste and uneaten feed. This result was not within the optimal range for the growth of African catfish C. gariepinus, namely 0.3 $\mathrm{mg} / \mathrm{L}$ which is in accordance with the Decision of the Minister of Environment No. 51 The year 2004. Later, ammonia level in each treatment decreased gradually and at the end of the study it reached $0.05-0.18 \mathrm{mg} / \mathrm{L}$ due to the activity of microorganism which oxidized ammonia into nitrite and nitrate (nitrification autotrophic bacteria) in each treatment which further transformed ammonia into bacterial biomass (heterotrophic bacteria). This finding was in line with the statement of Ray and Lotz (2014) that the decreasing ammonia level occurred due to ammonia utilization by the heterotrophic process of bacterial biosynthesis which produced bacterial biomass and nitrification chemoautotrophic process which produced nitrite compound then transformed it into nitrate.

Nitrate content in the maintenance media increased, yet it was not too significant. Increase in nitrate level was also reported by Avnimelech (2009) which reached $40(\mathrm{mg} / \mathrm{L})$ after 50 days of maintenance. Based on Bakar et al. (2015), it is not only phytoplankton that utilizes nitrate as the $\mathrm{N}$ source for its life in the biofloc application, yet several types of microbes include bacteria also use it.

Nitrite concentration which tended to be fluctuate indicated nitrification process in

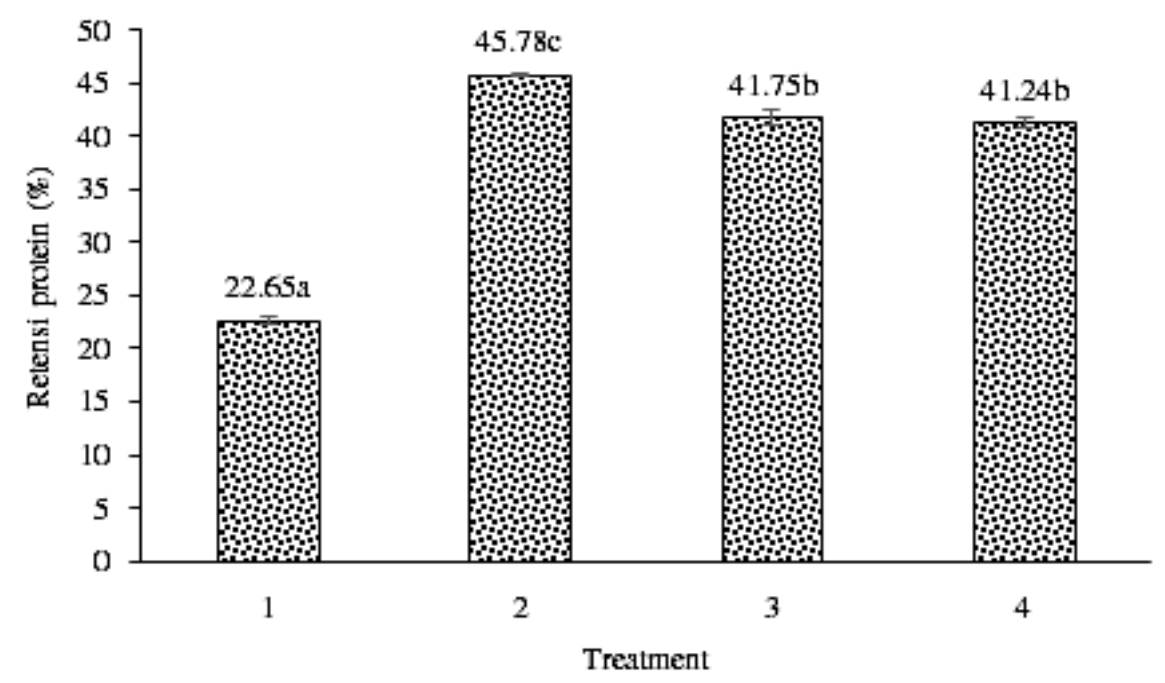

Figure 4. Average protein retention of African catfish Clarias gariepinus. 1. Biofloc pond at the stocking density of $1,000 \mathrm{fish} / \mathrm{m}^{3} ; 2$. The stocking density of $1,500 \mathrm{fish} / \mathrm{m}^{3} ; 3$. The stocking density of $2,000 \mathrm{fish} / \mathrm{m}^{3} ; 4$. The stocking density of $2,500 \mathrm{fish} / \mathrm{m}^{3}$. Value with different letter showed the significantly different result of ANOVA $(\mathrm{P}<0.05)$. 


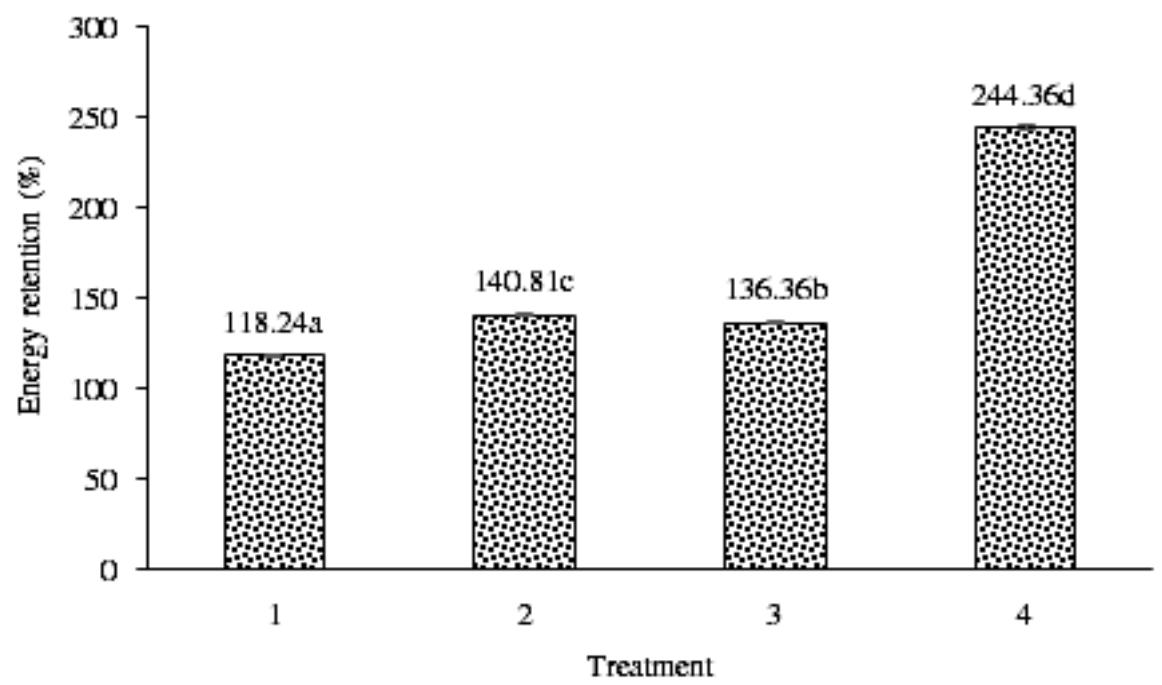

Figure 4. Energy retention of African catfish Clarias gariepinus. 1. Biofloc pond at the stocking density of 1,000 fish $/ \mathrm{m}^{3} ; 2$. The stocking density of $1,500 \mathrm{fish} / \mathrm{m}^{3} ; 3$. The stocking density of $2,000 \mathrm{fish} / \mathrm{m}^{3} ; 4$. The stocking density of $2,500 \mathrm{fish} / \mathrm{m}^{3}$. Value with different letter showed the significantly different result of ANOVA $(\mathrm{P}<0.05)$.

Table 1. Data on water quality during maintenance

\begin{tabular}{lcccc}
\hline \multirow{2}{*}{ Parameter } & \multicolumn{4}{c}{ Treatment of stocking density $\left(\mathrm{fish} / \mathrm{m}^{3}\right)$} \\
\cline { 2 - 5 } & 1,000 & 1,500 & 2,000 & 2,500 \\
\hline Temperature $\left({ }^{\circ} \mathbf{C}\right)$ & $25-29$ & $25-29$ & $25-29$ & $25-29$ \\
Dissolved oxygen $(\mathrm{mg} / \mathrm{L})$ & $7.6-8$ & 8 & $7.8-8$ & $7.4-8$ \\
Ammonia $\left(\mathrm{NH}_{3}\right)(\mathrm{mg} / \mathrm{L})$ & $0.18-1.04$ & $0.31-1.8$ & $0.05-0.9$ & $0.2-1.01$ \\
Nitrite $\left(\mathrm{NO}_{2}\right)(\mathrm{mg} / \mathrm{L})$ & $0.032-2.114$ & $0.005-3.657$ & $0.079-2.112$ & $0.034-1.997$ \\
Nitrate $\left(\mathrm{NO}_{3}\right)(\mathrm{mg} / \mathrm{L})$ & $5.492-12.171$ & $4.315-11.960$ & $5.479-10.903$ & $2.167-11.030$ \\
\hline
\end{tabular}

the maintenance media. The occurrence of nitrification process in the maintenance media is able to be seen by comparing the value of ammonia, nitrite, and nitrate, in which when the ammonia value is high, nitrite level tends to be low, vice versa. According to Avnimelech (2012), the main influence of nitrogen compound in the fish body is the occurrence of the change in oxygen transport and oxidation of compound in the tissue.

The temperature in African catfish maintenance media during the study was in the range of 25-29 ${ }^{\circ} \mathrm{C}$ (Table 1). This range of temperature was still within the optimal range for catfish rearing. Based on Kordi and Ghufran (2009), the optimal range of temperature for catfish culture was $25-30{ }^{\circ} \mathrm{C}$.

Dissolved oxygen plays an important role in aquaculture system, particularly in intensive culture system which applied biofloc technology. It is because the metabolic activity of microbes to decompose organic matter requires the continuous and sufficient amount of oxygen. The result of the measurement for dissolved oxygen (DO) in the water to be used as African catfish maintenance media was $7.4-8 \mathrm{mg} / \mathrm{L}$ which was still within the quality standard of aquaculture set by the Regulation of Government No. 28 the year 2001. Oxygen level is not only important for cell metabolic activity, but also may affect the floc structure. According to Wilen et al. (2008), at higher concentration of oxygen level, floc size will be larger and more compact thus it is easier for fish to utilize it as feed.

\section{CONCLUSION}

The result of the study showed that different high stocking density of African catfish $C$. gariepinus cultured in biofloc system was significantly different $(\mathrm{P}<0.05)$ from the absolute growth, energy retention, lipid retention, and protein retention of African catfish C. gariepinus. The best stocking density for growth was the density of $1,500 \mathrm{fish} / \mathrm{m}^{3}$. 


\section{REFERENCES}

Avnimelech Y. 2006. Bio-filters: The need for a new comprehensive approach. Aquaculture. 34: $172-178$.

Avnimelech Y. 2007. Feeding with microbial flocs by tilapia in minimal discharge bioflocs technology ponds. Aquaculture 264: 140-147.

Avnimelech Y. 2012. Biofloc Technology: A Practical Guide Book. 2 ${ }^{\text {nd }}$ Edition. United State: The World Aquaculture Society.

AvnimelechY, Kochba M. 2009. Evaluation of nitrogen uptaku and excretion by tilapia in bio flock tanks, using 15 ntracing. Aquaculture 287: 163-168.

Badiola M, Mendiola D, Bostock J. 2012. Recirculating aquaculture systems analysis: main issues on management and future challenges. Aquaculture Engineering: 51: 26-35.

Bakar NSA, Nasir NM, Lananan F, Hamid SHA, Lam SS, Jusoh A. 2015. Optimization of C/N ratios for nutrientremoval in aquaculture system culturing African catfish, Clarias gariepinus utilizing bioflocs technology. International Biodeterioration and Biodegradation 102: 100-106.

Ballester ELC, Abreu PC, Cavalli R, Emerenciano MM, Abreu LL, Wasielesky JrW. 2010. Effect of practical diets with different protein levels on the performance of Farfantepenaeus paulensis juveniles nursed in a zero exchange suspended microbial flocs intensive system. Aquaculture Nutrition. 16: 163-172.

Brune DE, Schwartz G, Eversole AG, Collier JA, Schwadler TE. 2003. Intensification of pond aquaculture and high rate photosynthetic systems. Aquaculture Engineering 28: 65-86.

Crab RM, Kochva W, Verstraete, Avnimelech Y. 2009. Bioflocs technology in over wintering of tilapia. Aquaculture Engineering 40: 105112.

Crab R, Bossier P, Avnimelech Y, Defoirdt T, Verstraete W. 2007. Nitrogen removal techniques in aquaculture for sustainable production. Aquaculture 270: 1-14.

De Schryver P, Crab R, Defroidt T, Boon N, Verstreate. 2008. The basics of bioflocs technology: the added value for aquaculture. Aquaculture 277: 125-137.

Ekasari J. 2009. Bioflocs technology: theory and application in intensive aquaculture system. Jurnal Akuakultur Indonesia 8: 117-226.
Ekasari J, Waluyo DASH, Bachtiar T, Surawidjaja EH, Bossier P, Schryver PD. 2014. The size of biofloc determines the nutritional composition and the nitrogen recovery by aquaculture animals. Aquaculture 426-427: 105-111.

Fujaya Y. 2004. Fisiologi Ikan Dasar Pengembangan Teknik Perikanan. Jakarta: Rineka Putra.

Furtado PS, Poersch LH, Wasielesky JrW. 2011. Effect of calcium hydroxide, carbonate and sodium bicarbonate on water quality and zootechnical performance of shrimp Litopenaeus vannamei reared in bio-flocs technology (BFT) systems. Aquaculture 321: 130-135.

Hapsari F. 2016. The effect of fermented and non fermented biofloc inoculated with bacterium bacillus cereus for catfish Clarias gariepinus juveniles. AACL Bioflux 9: 334-339.

Hermawan AT, Iskandar, Ujang, Subhan. 2012. Pengaruh padat tebar terhadap kelangsungan hidup pertumbuhan lele dumbo Clarias gariepinus Buroh. di kolam kali menir Indramayu. Jurnal Perikanan dan Kelautan 3: 85-93.

Hermawan TES, Sudaryono A, Prayitno SB. 2014. The effect of different stocking densities toward growth and survival rate of catfish seed Clarias gariepinus in biofloc media. Journal of Aquaculture Management and technology 3: 35-42.

Hickling CF. 1971. Fish Culture. London: Faber and Faber.

Kordi K, Ghufran HM. 2009. Budidaya Perairan Buku Kedua. Bandung: PT Citra Aditya Bakti.

Kuhn DD, Boardman GD, Lawrence AL, Marsh L, Flick Jr. 2009. Microbial floc meal as a replacement ingredient for fish meal and soybean protein in shrimp feed. Aquaculture 296: 51-57.

Malik A, Hameeda K, Sajjah AS, Kalhoro IB. 2014. The effect of different sotocking densities on growth, production and survival rate of pangas Pangasius hypophthalmus fish in cemented tanks at fish hatchery Chilya Thatta, Sindh-Pakistan. International Journal of Interdisciplinary and Multidisciplinary Studies 1: 129-136.

Nwipie GN, Erondu ES, Zabbey N. 2015. Influence of stocking density on growth and survival of post fry of the african mud catfish, Clarias gariepinus. Fisheries and Aquaculture Journal 6: 1-4.

[PAU] Pusat Antar Universitas. 2016. Laporan 
Hasil Uji. Yogyakarta: Pusat Studi Pangan dan Gizi, Universitas Gajah Mada.

Peraturan Pemerintah Republik Indonesia Nomor 82 Tahun 2001. Tentang Pengelolaan Kualitas Air dan Pengendalian Pencemaran Air. Jakarta: Sekretaris Negara Republik Indonesia.

Ray AJ, Lotz JM. 2014. Comparing a chemoautotrophic-based biofloc system and three heterotrophic-based systems receiving different carbohydrate sources. Aquacultural Engineering 63: 54-61.

Sidik AS, Sarwono, Agustina. 2002. The effect of stocking density on nitrification rate in a closed recirculating culture system. Jurnal Akuakultur Indonesia 1: 47-51.

Shafrudin D, Yuniarti, Setiawati M. 2006. Effect of rearing density of "dumbo" catfish Clarias sp. fry on production in the controlled nitrogen culture system by adding wheat powder. Jurnal Akuakultur Indonesia 5: 137-147.

Soedibya, Listiowati. 2014. Rekayasa bioflok pada budidaya ikan lele dumbo Clarias sp.: upaya peningkatan kinerja produksi budidaya dan ramah lingkungan [Laporan Penelitian].
Purwokerto: Lembaga Penelitian dan Pengabdian Masyarakat, UNSOED.

Sukardi P, Yuwono E. 2010. Nutrisi Ikan. Purwokerto : Unsoed Press.

Watanabe OW, Ellis SC, Chaves J. 2001. Effect of dietary lipid dan energy to protein ratio on growth dan feed utilization of juvenile mutton snapper Lutjanus analis fed isonitrogenous diets at two temperature. Journal of The World Aquaculture Society. 32: 30-40.

Wilen BM, Onuki M, Hermansson M, Lumley D, Mino T. 2008. Microbial community structure in activated sludge floc analyzed by fluorescence in situ hybridization and its relation to floc stability. Water Research 42: 2300-2308.

Yuwono E, Sukardi P. 2001. Fisiologi Hewan. Purwokerto: Faculty of Biology. Jenderal Soedirman University.

Zidni I, Herawati T, Liviawaty E. 2013. Pengaruh padat tebar terhadap pertumbuhan benih lele sangkuriang Clarias gariepinus dalam sistem akuaponik. Jurnal Perikanan Kelautan. 4: 315-324. 